\title{
Polymorphism in Escherichia coli: rtl atl and gat Regions Behave as Chromosomal Alternatives
}

\author{
By M. J. WOODWARD*† AND H. P. CHARLES \\ Department of Microbiology, University of Reading, London Road, Reading RG1 5AQ, U.K.
}

(Received 13 April 1982)

\begin{abstract}
Amongst forty wild strains of Escherichia coli, sixteen utilized galactitol (as did K12) and seven utilized ribitol (as did C) of which six utilized D-arabitol; none utilized all three polyols.

Transduction of genes for ribitol utilization $\left(\mathrm{rtl}^{+}\right)$to strains able to utilize galactitol $\left(\mathrm{gat}^{+}\right)$, whether $\mathrm{K} 12$ or wild strains, using wild strains and $E$. coli $\mathrm{C}$ as donors always resulted in loss of the galactitol phenotype. The genes for D-arabitol use $\left(a l^{+}\right)$were always cotransduced with $\mathrm{rl}^{+}$ in interstrain crosses. We confirm and extend the mapping of $\mathrm{gat}^{+}$(Lengeler, 1977) and $\mathrm{rll}^{+} \mathrm{atl}^{+}$ (Reiner, 1975) in their respective hosts, K12 and C, by showing both regions to be $50 \%$ cotransducible with $m e t G$ and $3 \%$ cotransducible with $f p k$. In reciprocal transductions, $g a t^{+}$ replaced $\mathrm{rl}^{+} \mathrm{atl}^{+}$. In partial diploids, $\mathrm{rl}^{+} \mathrm{atl}^{+}$and $\mathrm{gat}^{+}$regions did not interfere with each other's expression.

Transfer of $\mathrm{rtl}^{+}$from an $\mathrm{Rtl}^{+} \mathrm{Atl}^{-}$donor by $\mathrm{R}$ plasmid (pE10)-mediated conjugation, gave $\mathrm{Gat}^{-}$transconjugants of $\mathrm{K} 12$ in which $\mathrm{rtl}^{+}$and a kanamycin resistance gene were $100 \%$ cotransducible in the met $G$ region of the chromosome.

It is suggested that the $\mathrm{rll}^{+} \mathrm{atl}^{+}$and $\mathrm{gat}^{+}$genes (or parts of them) act as alternative, or mutually exclusive, regions in the chromosome. Possible reasons for the existence of alternative characters are discussed.
\end{abstract}

\section{INTRODUCTION}

An enormous amount of natural variation occurs in Escherichia coli and other members of the Enterobacteriaceae. As the first stage in studying the genetic basis of this variation, characters were chosen for which $E$. coli $\mathrm{K} 12$ is negative and for which some wild strains are positive. Tests were then made to determine whether the characters were transferrable to $\mathrm{K} 12$, and to determine whether their genes took constant chromosomal locations in K12. For ease of selection in genetic crosses, the characters of first choice were those concerned with utilization of carbohydrates. So far, sucrose utilization (Alaeddinoglu \& Charles, 1979; Hill, 1980; Hill \& Charles, 1980) and L-sorbose utilization (Woodward, 1980; Woodward \& Charles, 1980, 1982) have been studied. The genes for each character took a characteristic locus in K12. A study of ribitol, D-arabitol and galactitol utilization is now reported. These characters proved to be of special interest in that the genes for ribitol and D-arabitol utilization, on the one hand, and those for galactitol utilization on the other, behaved as mutually exclusive alternatives in the chromosome.

Ribitol and D-arabitol are used by $85 \%$ of Klebsiella strains (Cowan \& Steel, 1974) and $10 \%$ of $E$. coli strains (Edwards \& Ewing, 1972). Amongst laboratory strains, E. coli $\mathrm{C}$ utilizes ribitol and $\mathrm{D}$-arabitol but K12 and B do not (Reiner, 1975). Strains able to use ribitol and D-arabitol mutate to use xylitol (Mortlock et al., 1965; Wu et al., 1968) and this has been of interest in the study of enzyme evolution (Inderlied \& Mortlock, 1977) and gene duplication (Rigby et al., 1974). The $\mathrm{rtl}^{+} \mathrm{atl}^{+}$genes were transduced from $E$. coli C into K12 (Reiner, 1975) as were the $\mathrm{rbt}^{+} \mathrm{dal}^{+}$genes

† Address for correspondence: 7A Woodcote Lawns, Chesham, Bucks HP5 2LY, U.K. 
from $K$. aerogenes (Rigby et al., 1976). In both cases the genes, although distinct, showed $100 \%$ cotransduction and took a position near met $G$, at 46 min on the current linkage map (Bachmann \& Low, 1980).

Catabolism of ribitol and D-arabitol in $K$. aerogenes and $E$. coli depends upon different inducible operons, each coding for a dehydrogenase ( $r b t D$, dalD and $r t l A$, atl $A)$ and a kinase ( $r b t K$, dalK and $r t l A, a t l B$ ). The genes of the two operons are closely linked and lie in mirror image arrangements : dalK dalD dalC rbtB dalB rbtC $r b t D$ rbtK in $K$. aerogenes (Charnetzky \& Mortlock, 1974a, b, c) and rtlB rtlA rtlC atlC atlA atlB in E. coli (Scangos \& Reiner, 1978). The genetic and biochemical similarities of ribitol and D-arabitol utilization in $E$. coli and $K$. aerogenes led to the suggestion that Klebsiella was a likely source of the ribitol and D-arabitol genes in $E$. coli, if the genes originated extragenerically (Reiner, 1975). The fact that stable integration of Klebsiella genes into the $E$. coli chromosome occurs after R-plasmid-mediated conjugation (Cannon et al., 1974) and after P1 transduction (Rigby et al., 1976) may support this speculation.

Catabolism of galactitol in E. coli depends upon an inducible operon coding for a phosphoenolpyruvate-dependent phosphotransferase enzyme II (gat A) and a dehydrogenase (gat D); the genes are closely linked in the order gatC gat A gatD and map near met $G$ at 46 min on the linkage map (Lengeler, 1975a, 1977; Lengeler \& Steinberger, 1978).

\section{METHODS}

The methods used followed Alaeddinoglu \& Charles (1979), except when stated otherwise.

Lysogenization and transduction by PIclr100KM. These were as described by Goldberg et al. (1974) and as modified by Woodward \& Charles (1982). When appropriate, P1clr100KM lysogens of wild strains were used as recipients in transduction. Recipients were grown at $30^{\circ} \mathrm{C}$ with vigorous agitation in $\mathrm{T} 2$ broth supplemented with kanamycin $\left(12.5 \mathrm{mg}^{-1}\right)$. For transduction, $10^{9}$ bacteria, $10^{9}$ phage and $0.1 \mathrm{ml} \mathrm{CaCl}_{2}(0 \cdot 1 \mathrm{M})$ were mixed and adsorption was at $30^{\circ} \mathrm{C}$ for $25 \mathrm{~min}$.

Gene symbols and map distances. These follow Bachmann \& Low (1980), but the positive, rather than the wildtype alleles are indicated by a plus sign. Except in Table 1, genes are shown in their order on the linkage map starting at $0 \mathrm{~min}$. Following Reiner (1975), the symbols $\mathrm{rl}^{+}$and $\mathrm{atl}^{+}$represent genes, occurring in some wild strains, which confer the abilities to utilize ribitol and D-arabitol, respectively. The degree of homology between $\mathrm{rll}^{+} \mathrm{atl}^{+}$genes from $E$. coli C and from other wild strains is not known.

Strain designations and genotypes. These are shown in Table 1. Strain MW23 was obtained by mutagenesis of strain AB1621; the new allele ato-23 was similar to the ato A and atoB alleles (Pauli \& Overath, 1972) in blocking butyrate utilization and in being $50 \%$ cotransducible with nalA. Strain MW39 was made by mutagenesis of strain $\mathrm{AB} 1621$; the new allele gat-39 was similar to gatC, gat $A$ and gat D alleles (Lengeler, 1977) in blocking galactitol utilization and in mapping at $46 \mathrm{~min}$ in time-of-entry experiments.

\section{RESULTS}

\section{Acquisition of $\mathrm{rl}^{+}$atl $^{+}$genes caused $\mathrm{K12}$ to become $\mathrm{Gat}^{-}$}

Of forty strains tested, seven utilized ribitol and D-arabitol, one utilized ribitol only, and none used D-arabitol only. Treatment with sodium lauryl sulphate (Tomoeda et al., 1968) or acridine orange (Salisbury et al., 1972) did not cause loss of the ribitol and D-arabitol characters, suggesting that the characters were not due to plasmids. P1 kc did not give plaques on the wild strains. The method of Goldberg et al. (1974), modified by Woodward \& Charles (1982), gave P1clr100KM lysogens of each ribitol-positive strain. The lysogens were induced at $42^{\circ} \mathrm{C}$. Lysates of RK11, RK52, RK95 and RK120 gave about $10^{9}$ plaques $\mathrm{ml}^{-1}$ when assayed on restrictionless mutant $5 \mathrm{~K}$, and were used to transduce $\mathrm{K} 12$ recipients (Table 2). Control selection for $\operatorname{ArgA}^{+}$and $\mathrm{MetB}^{+}$gave frequencies of transduction and cotransduction comparable with those for $\mathrm{K} 12$ to $\mathrm{K} 12$ crosses (McConville, 1977). Rt1 ${ }^{+}$transductants occurred with frequencies similar to $\mathrm{Xyl}^{+}$transductants. Lysates of RK1, RK6, RK65 and RK79 contained about $10^{4}$ phage $\mathrm{ml}^{-1}$, insufficient for transduction.

Reiner (1975) showed that genes $\mathrm{rl}^{+}$and $\mathrm{atl}^{+}$, conferring ability to utilize ribitol and Darabitol, were $95 \%$ cotransducible within $E$. coli $\mathrm{C}$, and $100 \%$ cotransducible when transduced 
Table 1. Escherichia coli strains

Strain

AB1621
AT2243-11
JC1553
JC5466
KL144
MLM161
N1332
SB1803
5K
AB2575
GA312
GA997
KL983
R4
44
MW16
MW23
MW39
MW81
MW111-3
MW521-3
MW591-3
MW1201-3
MW5651-4
RK1-120

Genotype

$\mathrm{F}^{-}$ara lac tsx gal xyl mil glpD thiA

$\mathrm{F}^{-}$tonA22 relA1 fpk-1 uhp-1 pyrE41 metB1

$\mathrm{F}^{-}$leu his recA rpsL malA argG met $B$

$\mathrm{F}^{-}$trp his recA rpsL

$\mathrm{F}^{-}$tonA2 tsx relA aroC purF recA rpsL

$\mathrm{F}^{-}$his rpsL mal mil ilv metB $\mathrm{glpK}$ arg $H$

$\mathrm{F}^{-}$proB lacZ118 trpA605 nalA rpsL recA200ts metE

$\mathrm{F}^{-}$thr-1 leu-6 proA2 ara lacY supE44 galK2

hisC3 metG83 rpsL mtl xyl

$\mathrm{F}^{-}$thr-1 leu-6 lacY tonA21 hsdR514 rpsL

Hfr tsx ilv thiA

VHfr sac ${ }^{+}$thr-1 leu-6 rpsL

Hfr $\mathrm{sac}^{+}$dapC relA thi-1

Hfr lacY $m g l P 1 \quad x y l-7$

Hfr relAl metBI

Hfr galT23 argS41 argA42 $\operatorname{argR40}$ ilv-282

$\mathrm{rl}^{+} \mathrm{atl}^{+}$transductant of strain Hfr44, donor MW111

ato-23 mutant of strain $\mathrm{AB} 1621$ made by $\mathrm{MNNG}$ mutagenesis

gat-39 mutant of strain AB1621 made by MNNG mutagenesis

$\mathrm{rtl}^{+}$atl $\mathrm{l}^{+} \mathrm{recA}$ purF aroC argH thi-l

$\mathrm{rll}^{+} \mathrm{atl}^{+}$transductants of strain AB1621, donor RK 11

$\mathrm{rl}^{+} \mathrm{atl}^{+}$transductants of strain AB1621, donor RK52

$\mathrm{rll}^{+} \mathrm{atl}^{+}$transductants of strain AB1621, donor RK95

$\mathrm{rll}^{+} \mathrm{atl}^{+}$transductants of strain AB1621, donor RK120

$\mathrm{rll}^{+}$transconjugants of strain 5K, donor RK65pE10

Wild strains isolated from the River Kennet
Source or reference

Adelberg et al. (1965)

Ferenci \& Kornberg (1973)

Clark \& Marguiles (1965)

Clark \& Marguiles (1965)

Low (1973)

McConville \& Charles (1979)

G. I. Lloyd, Nottingham

Blumenthal (1972)

Colson et al. (1965)

Pittard et al. (1963)

Alaeddinoglu \& Charles (1979)

Alaeddinoglu \& Charles (1979)

Low (1973)

Reeves (1959)

Cooper et al. (1969)

This work

This work

This work

This work

This work

This work

This work

This work

This work

This work

Table 2. Transduction of genes from $E$. coli wild strains into $K 12$

\begin{tabular}{|c|c|c|c|c|c|c|c|}
\hline Donor & $\begin{array}{l}\text { Phage } \\
\text { titre* }\end{array}$ & Recipient & $\begin{array}{l}\text { Selected } \\
\text { allele }\end{array}$ & $\begin{array}{l}\text { Transductants } \\
\text { per } 10^{7} \text { phage }\end{array}$ & $\begin{array}{l}\text { Number } \\
\text { scored }\end{array}$ & $\begin{array}{l}\text { Unselected } \\
\text { allele }\end{array}$ & $\begin{array}{l}\text { Cotransduction } \\
\text { frequency }(\%)\end{array}$ \\
\hline \multirow[t]{3}{*}{ RK11 } & $6.3 \times 10^{8}$ & MLM161 & $\begin{array}{l}\arg H^{+} \\
\operatorname{met}^{+}\end{array}$ & $\begin{array}{l}3.7 \\
4\end{array}$ & $\begin{array}{l}200 \\
200\end{array}$ & $\begin{array}{l}\operatorname{met} B^{+} \\
\arg H^{+}\end{array}$ & $\begin{array}{l}37 \\
44\end{array}$ \\
\hline & & AB1621 & $\mathrm{rtl}^{+}$ & 1 & 107 & $\mathrm{atl}^{+}$ & 100 \\
\hline & & & $x y l^{+}$ & 3.7 & - & - & - \\
\hline \multirow[t]{4}{*}{ RK52 } & $8.7 \times 10^{8}$ & MLM161 & $\operatorname{argH} H^{+}$ & $7 \cdot 5$ & 244 & met $^{+}$ & 21 \\
\hline & & & met $B^{+}$ & 6 & 326 & $\arg H^{+}$ & 16 \\
\hline & & AB162I & $\mathrm{rtl}^{+}$ & 4 & 407 & $a t l^{+}$ & 100 \\
\hline & & & $x y l^{+}$ & 9 & - & - & - \\
\hline \multirow[t]{4}{*}{ RK95 } & $1.4 \times 10^{9}$ & MLM161 & $\arg H^{+}$ & 15 & 500 & $\mathrm{metB}^{+}$ & 23 \\
\hline & & & met $B^{+}$ & 22 & 500 & $\arg H^{+}$ & 26 \\
\hline & & $\mathrm{AB} 1621$ & $\mathrm{rtl}^{+}$ & 1.2 & 117 & atl $^{+}$ & 100 \\
\hline & & & $x y l^{+}$ & 8 & - & - & - \\
\hline \multirow[t]{4}{*}{ RK 120} & $1.2 \times 10^{9}$ & MLM161 & $\arg H^{+}$ & 8 & 500 & $\operatorname{met}^{B^{+}}$ & 50 \\
\hline & & & met $^{+}$ & 8 & 500 & $\operatorname{argh} H^{+}$ & 32 \\
\hline & & AB1621 & $r t l^{+}$ & 0.8 & 81 & $\mathrm{atl}^{+}$ & 100 \\
\hline & & & $x y l^{+}$ & 6 & - & - & - \\
\hline
\end{tabular}

from $E$. coli $\mathrm{C}$ to $\mathrm{K} 12$. All the $712 \mathrm{rtl}^{+}$transductants in Table 2 proved to be $\mathrm{atl}^{+}$, contrasting with their recipient parent $\mathrm{AB} 1621$ which, like other $\mathrm{K} 12$ derivatives, did not use D-arabitol.

The possibility was examined that when bacteria acquired the $\mathrm{rtl}^{+}$region of the chromosome they might lose a corresponding region which coded for other characters. A K12 $\mathrm{rtl}^{+}$ transductant from each interstrain cross was tested for gain or loss of ability to use any of 212 
substances as carbon and energy sources. One difference was observed : all hybrids had lost the ability to use galactitol. About $4000 \mathrm{rtl}^{+}$transductants have now been tested: all had gained the ability to use D-arabitol and lost the ability to use galactitol, regardless of whether the donor was RK11, RK52, RK95 or RK120.

\section{Genes $\mathrm{rl}^{+}, \mathrm{atl}^{+}$and $\mathrm{gat}^{+}$mapped near met $\mathrm{G}$}

The $\mathrm{rl}^{+}$genes were mapped by interrupted conjugation. Three $\mathrm{rl}^{+}$transductants from each of the original crosses, designated MW111 to MW113, MW521 to MW523, MW591 to MW593 and MW1201 to MW1203 (from donors RK11, RK52, RK95 and RK120, respectively) were used as donors to transduce HfrGA997 and HfrGA312 to $\mathrm{rll}^{+}$. The $\mathrm{rll}^{+}$derivatives of these $\mathrm{Hfr}$ strains transferred the $\mathrm{rtl}^{+}$genes after $30 \mathrm{~min}$ and $75 \mathrm{~min}$, respectively, indicating a locus between his (44 $\mathrm{min})$ and sac $(50.5 \mathrm{~min})$. Using a $\mathrm{rtl}^{+}$derivative of GA997 as donor and SB1803 ( his metG rpsL) as recipient, selection was made separately for $\mathrm{his}^{+}, \mathrm{rtl}^{+}, \mathrm{metG}^{+}(47 \mathrm{~min})$ and $\mathrm{sac}^{+}$transconjugants. The genes were transferred at intervals of 4,1 and $2 \mathrm{~min}$, respectively. The results placed $\mathrm{rtl}^{+}$in the $46 \mathrm{~min}$ region, which contains three known markers (Bachmann \& Low, 1980). Mapping of markers in the 44-48 min region has been mainly by conjugation (B. J. Bachmann, personal communication). Tests were made for cotransduction of $\mathrm{rtl}^{+}$with his, $m g l P l, f p k, m e t G$, ato and nalA (Table 3), using phage P1kc and donor MW111. Selection was made for $\mathrm{Rtl}^{+}$and for the other wild-type alleles when possible, but $\mathrm{MglPl}^{+}$and $\mathrm{NalA}^{+}$were not selectable. The allele $m g l P 1$ reverted with a frequency of about $10^{-5}$ and distinction between transductants and revertants was not possible; nal $A^{+}$conferred sensitivity to nalidixic acid. The $r t l^{+}$region was cotransduced with $\operatorname{met} G(53 \%)$ and with $f p k^{+}(3 \%)$, but not with his, $m g l P 1$, ato or nalA. Further mapping was not attempted. About $2000 \mathrm{rt}^{+}$transductants from the mapping experiments were streaked on D-arabitol and galactitol; all used $\mathrm{D}$-arabitol and none used galactitol.

Lengeler $(1975 a, b)$ mapped the galactitol utilization genes $\left(\mathrm{gat}^{+}\right)$by time-of-entry at about $46 \mathrm{~min}$, but did not report their order with respect to nearby markers. According to Lengeler (1977), the original K12 from Lederberg's collection, most $\mathrm{F}^{-}$and a few $\mathrm{Hfr}$ strains use galactitol at $30^{\circ} \mathrm{C}$ and below, but some do not. Tests showed that some of our marker strains used galactitol at $30^{\circ} \mathrm{C}\left(\mathrm{gat}^{+}\right)$and others did not $(\mathrm{gat})$, and this variation was used to map the $\mathrm{gat}^{+}$region. In time-of-transfer experiments GA997 $\mathrm{gat}^{+}$was mated with MLM161 (his gat) and selection was made separately for $\mathrm{His}^{+}, \mathrm{Gat}^{+}$and $\mathrm{Sac}^{+}$. The genes were transferred after 27, 25 and $19 \mathrm{~min}$, respectively, confirming Lengeler's report. Amongst the strains available with nearby markers, SB1803 (metG) and MW23 (ato) were gat ${ }^{+}$, and MLM161 (his) and AT2243-11 ${ }^{c_{-}}$ $25(f p k)$ were $g a t$; Table 4 shows that $f p k^{+}$was $3 \%$ cotransducible with $g a t^{+}$, and a gat allele was $49 \%$ cotransducible with met $^{+}$.

\section{Partial diploids expressed $\mathrm{gat}^{+}$and $\mathrm{rtl}^{+}$atl $^{+}$}

Introduction of the $\mathrm{rll}^{+} \mathrm{atl}^{+}$region caused $\mathrm{Gat}^{+}$bacteria to become $\mathrm{Gat}^{-}$either because their $\mathrm{gat}^{+}$genes were replaced, or disrupted, or blocked in expression. Partial diploids were prepared,

Table 3. Cotransduction frequencies in the rtl region (donor strain MW111)

\begin{tabular}{|c|c|c|c|c|c|}
\hline Recipient & $\begin{array}{l}\text { Selected } \\
\text { allele }\end{array}$ & $\begin{array}{l}\text { Transductants } \\
\text { per } 10^{7} \text { phage }\end{array}$ & $\begin{array}{l}\text { Number } \\
\text { scored }\end{array}$ & $\begin{array}{l}\text { Unselected } \\
\text { allele }\end{array}$ & $\begin{array}{l}\text { Cotransduction } \\
\text { frequency }(\%)\end{array}$ \\
\hline \multirow[t]{2}{*}{ MLM161 } & $h_{i s}^{+}$ & 22 & 500 & $\mathrm{rtl}^{+}$ & 0 \\
\hline & $r l^{+}$ & $9 \cdot 5$ & 500 & $h i s^{+}$ & 0 \\
\hline KL983 & $r t l^{+}$ & 6 & 400 & $\mathrm{mglPI}^{+}$ & 0 \\
\hline \multirow[t]{2}{*}{ AТ $2243-11^{c}-25$} & $f p k^{+}$ & $28 \cdot 6$ & 540 & $r t l^{+}$ & 0 \\
\hline & $\mathrm{rtl}^{+}$ & 7 & 250 & $f p k^{+}$ & 3 \\
\hline \multirow[t]{2}{*}{ SB1803 } & $m e t G^{+}$ & 4 & 200 & $\mathrm{rtl}^{+}$ & 54 \\
\hline & $r l^{+}$ & 4 & 200 & $m e t G^{+}$ & 81 \\
\hline \multirow[t]{2}{*}{ MW23 } & ato- $23^{+}$ & 7 & 450 & $r l^{+}$ & 0 \\
\hline & $r l^{+}$ & 6 & 320 & ato $-23^{+}$ & 0 \\
\hline N1332 nalA $^{+}$ & $\mathrm{rtl}^{+}$ & 7 & 400 & nalA & 0 \\
\hline
\end{tabular}


Table 4. Cotransduction frequencies in the gat region

\begin{tabular}{|c|c|c|c|c|c|c|}
\hline Donor & Recipient & $\begin{array}{l}\text { Selected } \\
\text { allele }\end{array}$ & $\begin{array}{l}\text { Transductants } \\
\text { per } 10^{7} \text { phage }\end{array}$ & $\begin{array}{l}\text { Number } \\
\text { scored }\end{array}$ & $\begin{array}{c}\text { Unselected } \\
\text { allele }\end{array}$ & $\begin{array}{l}\text { Cotransduction } \\
\text { frequency }(\%)\end{array}$ \\
\hline \multirow[t]{2}{*}{$\mathrm{AB} 1621$} & MLM161 & his $^{+}$ & 21 & 500 & $\mathrm{gat}^{+}$ & 0 \\
\hline & & $\mathrm{gat}^{+}$ & 9 & 500 & his $^{+}$ & 0 \\
\hline \multirow[t]{2}{*}{$A B 1621$} & AT2243-1 $1^{\mathrm{c}}-25$ & $f p k^{+}$ & 24 & 500 & $g a t^{+}$ & 0 \\
\hline & & $\mathrm{gat}^{+}$ & 5 & 230 & $f p k^{+}$ & 3 \\
\hline MW39 & SB 1803 & metG $^{+}$ & 4 & 200 & gat & 49 \\
\hline MW39 & MW23 & ato $-23^{+}$ & 7 & 500 & gat & 0 \\
\hline
\end{tabular}

to show whether $\mathrm{gat}^{+}$genes were expressed in the presence of the $\mathrm{rll}^{+} a t l^{+}$region. $\mathrm{Hfr} 44$ was transduced to $\mathrm{rl}^{+} \mathrm{atl}^{+}$using donor MW111. One transductant, MW16, was purified and shown to utilize ribitol and D-arabitol but not galactitol. It transferred $\mathrm{rl}^{+} \mathrm{atl}^{+}$after about $100 \mathrm{~min}$, a little after his, consistent with a locus at $46.5 \mathrm{~min} . \mathrm{F}^{\prime} \mathrm{rtl}^{+}$atl ${ }^{+}$plasmids were obtained from conjugation between MW16 and recipient $\mathrm{JC1} 1553$ ( his $_{\text {gat }}{ }^{+}$rec A rpsL). Selection for $\mathrm{His}^{+} \mathrm{Rtl}^{+}$, 20 min after mixing gave about 200 transconjugants from plating $10^{6}$ donors and $10^{7}$ recipients; all utilized galactitol, ribitol and D-arabitol.

$\mathrm{F}^{\prime}$ plasmids carrying $\mathrm{gat}^{+}$were obtained by mating $\mathrm{Hfr} 44\left(\mathrm{his}^{+} \mathrm{gat}^{+}\right)$with MLM161 (his gat rpsL), selection being made for $\mathrm{His}^{+} \mathrm{Gat}^{+}$transconjugants after 20 min conjugation. About $200 \mathrm{His}^{+} \mathrm{Gat}^{+}$transconjugants were obtained. One was tested in conjugation with MW81 $\left(\mathrm{rtl}^{+} \mathrm{atl}^{+} \mathrm{recA}\right.$ ), selection being made for $\mathrm{Gat}^{+}$recipients. Mating mixtures contained $10^{6}$ donors and $10^{7}$ recipients $\mathrm{ml}^{-1}$; one in five donors transferred their $\mathrm{F}^{\prime}$ his $^{+}$gat $^{+}$plasmids. About $1000 \mathrm{Gat}^{+}$transconjugants were purified by streaking three times on complete medium; all grew as well as $\mathrm{Gat}^{+}$and $\mathrm{Rt}^{+} \mathrm{Atl}^{+}$haploids when streaked on galactitol, ribitol and Darabitol media.

The experiments with partial diploids suggested that the loss of the $\mathrm{Gat}^{+}$character on introduction of the $\mathrm{rtl}^{+} \mathrm{atl}^{+}$region was due to replacement of the $\mathrm{gat}^{+}$genes, or interruption of an operon by insertion of incoming DNA. If the damage to the gat $^{+}$genes was small, it was possible that $\mathrm{rll}^{+} \mathrm{atl}^{+}$hybrids might be able to revert to $\mathrm{Gat}^{+}$by genetic rearrangement, or by loss of the $\mathrm{rl}^{+} \mathrm{atl}^{+}$genes. Also, sufficient of the $\mathrm{gat}^{+}$DNA sequence might remain in hybrids for them to provide, in transduction, the DNA sequences required to restore some of the $N$-methyl$N^{\prime}$-nitro- $N$-nitrosoguanidine (MNNG)-induced gat mutants to $\mathrm{Gat}^{+}$. Transduction tests, and tests with common mutagens, failed to give $\mathrm{Gat}^{+}$mutants from $\mathrm{rl}^{+} \mathrm{atl}^{+}$hybrids.

\section{Wild strains utilizing galactitol did not use ribitol or D-arabitol}

If the $\mathrm{rtl}^{+} \mathrm{atl}^{+}$region and the $\mathrm{gat}^{+}$region were alternatives in the chromosome, then wild strains able to utilize all three substrates might not occur. Forty wild strains and strains $B$ and $C$ were streaked onto galactitol, ribitol and D-arabitol media. Seven strains, including E. coli $\mathrm{C}$, utilized ribitol and D-arabitol, and one utilized ribitol alone; none of these utilized galactitol. Fourteen grew well on galactitol at $30^{\circ} \mathrm{C}$ giving colonies of $2 \mathrm{~mm}$ diameter within $4 \mathrm{~d}$; one gave translucent colonies of $0.5 \mathrm{~mm}$ diameter within $12 \mathrm{~d}$ and $E$. coli $\mathrm{B}$ mutated to use galactitol; none used ribitol or arabitol. The remaining strains used neither galactitol, ribitol nor D-arabitol.

\section{Wild strains transduced to $\mathrm{Rtl}^{+} \mathrm{Atl}^{+}$became $\mathrm{Gat}^{-}$, and vice versa}

To test whether $\mathrm{rll}^{+} \mathrm{atl}^{+}$genes were expressed in $\mathrm{gat}^{+}$wild strains, $\mathrm{F}^{\prime} \mathrm{rll}^{+} \mathrm{atl}^{+}$plasmids were used. JC5466 (trp his recA// $\mathrm{F}^{\prime} \mathrm{rl}^{+} \mathrm{atl}^{+}$his $^{+}$) was incubated with $\mathrm{gat}^{+}$strains and selection made for transconjugants able to utilize ribitol. They occurred with frequencies ranging from one per 50 donors to one per $10^{8}$ donors in 12 of the 14 crosses; 10 transconjugants from each were tested by streaking and grew well on ribitol, D-arabitol and galactitol media.

In order to transduce $\mathrm{rl}^{+} \mathrm{atl}^{+}$genes into $\mathrm{Gat}^{+}$wild strains, Plclr100KM lysogens of wild strains were first prepared to serve as recipients. Lysogens of $10 \mathrm{Gat}^{+}$wild strains (RK strains 2 , $19,20,42,53,87,91,99,101$ and 107) from 16 tested were obtained using the modified method of Woodward \& Charles (1982). Phage P1kc grown on MW111 was used to transduce the lysogens, selection being made for $\mathrm{Rtl}^{+}$transductants. For every $10^{9}$ infecting particles derived from 
MW111, RK2 gave $3 \mathrm{rtl}^{+}$transductants, RK19 gave 1, RK42 gave 42, RK91 gave 117, and the other 6 strains gave none. In these experiments $489 \mathrm{rtl}^{+}$transductants were obtained; all utilized D-arabitol and none utilized galactitol.

To check that $\mathrm{gat}^{+}$genes were expressed in $\mathrm{rll}^{+} \mathrm{atl}^{+}$bacteria, JC5466 (trp his rec $/ / \mathrm{F}^{\prime}$ his $^{+} \mathrm{gat}^{+}$) was incubated with wild strains, RK1, RK6, RK11, RK52, RK65, RK79, RK95 and RK120, and selection made for $\mathrm{Gat}^{+}$transconjugants. They were obtained from each mating with frequencies between one per $10^{6}$ and one per $10^{8}$ donors. Ten transconjugants from each were tested; they utilized galactitol, ribitol and D-arabitol.

P1kc phage from AB1621 ( gat $\left.^{+}\right)$was used to transduce MW111, E. coli C and P1clr100KM lysogens of $\mathrm{Rtl}^{+} \mathrm{Atl}^{+}$wild strains, selection being made for $\mathrm{Gat}^{+}$. MW111, E. coli C, RK1, RK95 and RK120 gave transductants, but RK6, RK11, RK52, RK65 and RK79 did not. Of $485 \mathrm{Gat}^{+}$ transductants none utilized ribitol or D-arabitol.

Phage suspensions were also prepared by induction of P1clr100KM lysogens of $\mathrm{Gat}^{+}$wild strains. Those from RK4, RK19 and RK20 contained at least $10^{7}$ phage $\mathrm{ml}^{-1}$, which were sufficient for use in transduction, but those from seven other $\mathrm{Gat}^{+}$lysogens contained only $10^{3}$ $10^{5} \mathrm{inl}^{-1}$. Transductions with MW111 as recipient were successful. Of almost $1000 \mathrm{Gat}^{+}$ transductants none utilized either ribitol or D-arabitol. Transductions with $\mathrm{Rtl}^{+} \mathrm{Atl}^{+}$ P1clr100KM lysogenic wild strains as recipients failed.

\section{Transfer of the $R \mathrm{tl}^{+}$genes from $\mathrm{RK65}\left(\mathrm{Rtl}^{+} \mathrm{Atl}^{-}\right)$by conjugation}

Amongst eight wild strains which utilized ribitol, RK65 was unique in that it did not utilize Darabitol. Although readily lysogenized by $\mathrm{P} 1 \mathrm{clr} 100 \mathrm{KM}$, it gave insufficient phage for transduction. Plasmid $\mathrm{pE} 10$ was used for the conjugative transfer of chromosomal $\mathrm{sac}^{+}$genes from wild strains to K12 by Alaeddinoglu \& Charles (1979). Following their methods, pE10 was transferred to RK65 and the bacteria were grown overnight with strain $5 \mathrm{~K}$, which lacks a restriction endonuclease. Selections were then made for $\mathrm{Rtl}^{+}$, $\mathrm{Thr}^{+}$and $\mathrm{Leu}^{+}$transconjugants, with streptomycin selecting against the donor. Four $\mathrm{Rtl}^{+}$colonies were obtained from two matings (about one per $2 \times 10^{9}$ donors); $\mathrm{Thr}^{+}$and $\mathrm{Leu}^{+}$colonies were not obtained. Bacteria from the $\mathrm{Rtl}^{+}$colonies carried the genetic markers of $5 \mathrm{~K}$ except that they utilized ribitol and were resistant to kanamycin, chloramphenicol, neomycin, ampicillin and tetracycline. The hybrids were given the symbols MW5651-MW5654.

The four 5K ( $\left.r \mathrm{ll}^{+}\right)$hybrids and JC1553 (pE10) were treated with sodium lauryl sulphate which causes the loss of pE10 from host bacteria (Alaeddinoglu \& Charles, 1979). The hybrids lost neither the ability to use ribitol, nor resistance to kanamycin, but they lost resistance to chloramphenicol, neomycin, ampicillin and tetracycline en bloc from $6 \%$ of treated bacteria. $\mathrm{JC1} 553$ (pE10) lost all five resistances, kanamycin included, en bloc from $5 \%$ of treated bacteria. It seemed that pE10 or a derivative was present in each hybrid. If $\mathrm{rl}^{+}$had become inserted into $\mathrm{pE} 10$, it should enable the transfer of $r \mathrm{ll}^{+}$to $\mathrm{rec} A$ recipients. This was tested using the four hybrids as donors and $\mathrm{AB} 1621\left(\mathrm{recA} \mathrm{A}^{+}\right)$and $\mathrm{KL} 144(\mathrm{recA})$ as recipients. Selections were made for $\mathrm{Rtl}^{+}$transconjugants, for transconjugants resistant to both kanamycin and chloramphenicol, and for $\mathrm{Rtl}^{+}$transconjugants resistant to kanamycin (Table 5); selection against the donor was achieved by omitting threonine and leucine from the medium.

Transconjugants occurred on ribitol minimal medium with and without kanamycin at a frequency of about one per $2 \times 10^{7}$ donors, but only when the recipient was rec $A^{+}$. One hundred of each class of transconjugants, selected for $\mathrm{rll}^{+}$and $\mathrm{rtl}^{+} \mathrm{Kan}^{\mathrm{R}}$ (800 in total), were tested and all were resistant to kanamycin, chloramphenicol, neomycin, tetracycline and ampicillin.

Selection for kanamycin and chloramphenicol resistance gave about one transconjugant per 50 donors with both $\operatorname{rec} A^{+}$and $\operatorname{rec} A$ recipients $; 2000$ were tested and all were unable to use ribitol but were resistant to neomycin, tetracycline and ampicillin. This was evidence that the four hybrids harboured intact and autonomously-transmissible pE10, which did not carry the $\mathrm{rl}^{+}$ genes.

The failure to isolate $\mathrm{Rtl}^{-}$strains by treatment with sodium lauryl sulphate and the high frequency of transfer of $\mathrm{Rtl}^{+}$to $\operatorname{rec} \mathrm{A}^{+}$but not $r e c A$ recipients, suggested that the $r t l^{+}$genes were chromosomal in the four hybrids. To test this, $\mathrm{rl}^{+}$was transduced from them into Hfr strains 
Table 5. Conjugation experiments with $5 K\left(r t l^{+} K^{2} n^{R}\right)$ hybrids as donors

Frequency of transfer per donor when selection was made for:

\begin{tabular}{|c|c|c|c|c|}
\hline \multirow[b]{2}{*}{ Donor } & \multirow[b]{2}{*}{ Recipient } & \multirow[b]{2}{*}{$\mathrm{rtl}^{+}$} & \multirow[b]{2}{*}{$r t l^{+} \mathrm{Kan}^{\mathrm{R} *}$} & \\
\hline & & & & $\mathrm{Kan}^{\mathrm{R}}, \mathrm{Cam}^{\mathrm{R} *}$ \\
\hline \multirow[t]{2}{*}{ MW5651 } & AB1621 & $6.3 \times 10^{-7}$ & $6.1 \times 10^{-7}$ & $3.4 \times 10^{-2}$ \\
\hline & KL144 recA & 0 & 0 & $2.7 \times 10^{-2}$ \\
\hline \multirow[t]{2}{*}{ MW5652 } & AB 1621 & $7.4 \times 10^{-7}$ & $7 \cdot 1 \times 10^{-7}$ & $1.7 \times 10^{-2}$ \\
\hline & KLI44 recA & 0 & 0 & $1.7 \times 10^{-2}$ \\
\hline \multirow[t]{2}{*}{ MW5653 } & $\mathrm{AB} 1621$ & $3.2 \times 10^{-7}$ & $3.2 \times 10^{-7}$ & $8.2 \times 10^{-2}$ \\
\hline & KL144 recA & 0 & 0 & $4.3 \times 10^{-2}$ \\
\hline \multirow[t]{2}{*}{ MW5654 } & $\mathrm{AB} 1621$ & $7.4 \times 10^{-7}$ & $6.0 \times 10^{-7}$ & $6.0 \times 10^{-2}$ \\
\hline & KLl44 rec $A$ & 0 & 0 & $3.4 \times 10^{-2}$ \\
\hline
\end{tabular}

Table 6. Transduction experiments with $5 \mathrm{~K}\left(\mathrm{rtl}^{+} \mathrm{Kan}^{R}\right)$ hybrids as donors

\begin{tabular}{|c|c|c|c|c|c|c|}
\hline Donor & Recipient & $\begin{array}{c}\text { Marker } \\
\text { selected* }\end{array}$ & $\begin{array}{l}\text { Transductants } \\
\text { per } 10^{7} \text { phage }\end{array}$ & $\begin{array}{l}\text { Unselected } \\
\text { marker } \\
\text { scored }^{*}\end{array}$ & $\begin{array}{c}\text { Number } \\
\text { tested }\end{array}$ & $\begin{array}{l}\text { Number } \\
\text { sharing } \\
\text { cotransduction }\end{array}$ \\
\hline \multirow[t]{7}{*}{ MW5651 } & AB 1621 & $x y l^{+}$ & 8 & - & - & - \\
\hline & & $r t l^{+}$ & 2 & $\operatorname{Kan}^{\mathbf{R}}$ & 200 & 200 \\
\hline & & & & $\mathrm{Cam}^{\mathbf{R}}$ & 200 & 0 \\
\hline & KL144 recA & $\operatorname{aroc}^{+}$ & 0 & - & - & - \\
\hline & & $\mathrm{rtl}^{+}$ & 0 & - & - & - \\
\hline & & $\operatorname{Kan}^{\mathbf{R}}$ & 0.5 & $\mathrm{Cam}^{\mathrm{R}}$ & 50 & 50 \\
\hline & & & & $r t l^{+}$ & 50 & 0 \\
\hline \multirow[t]{7}{*}{ MW5652 } & AB1621 & $x y l^{+}$ & 9 & - & - & - \\
\hline & & $\mathrm{rtl}^{+}$ & 3 & $\mathrm{Kan}^{\mathbf{R}}$ & 50 & 50 \\
\hline & & & & $\mathrm{Cam}^{\mathrm{R}}$ & 50 & 0 \\
\hline & KL144 recA & $\operatorname{aroc}^{+}$ & 0 & - & - & - \\
\hline & & $r t l^{+}$ & 0 & - & - & - \\
\hline & & $\mathrm{Kan}^{\mathrm{R}}$ & 0.4 & Cam $^{R}$ & 41 & 41 \\
\hline & & & & $r t l^{+}$ & 41 & 0 \\
\hline
\end{tabular}

AB2575 and R4, which transferred different regions of the chromosome and, unlike 5K, were $\mathrm{gat}^{+}$. About $800 \mathrm{rtl}^{+}$colonies, $100 \mathrm{from}$ each experiment, were tested. All were resistant to kanamycin and sensitive to the other antibiotics. They did not utilize galactitol, suggesting that the $\mathrm{rll}^{+}$genes had taken the usual chromosomal position at about $46 \mathrm{~min}$. This was tested by conjugation, using the $\mathrm{rtl}^{+} \mathrm{Kan}^{\mathrm{R}}$ derivatives of $\mathrm{Hfr}$ strains AB2575 and R4 separately as donors with MLM161 (his $\mathrm{gat}^{+}$) as recipient, and selecting separately for $\mathrm{Rtl}^{+}$and $\mathrm{His}^{+}$. The AB2575 derivative transferred $\mathrm{rll}^{+}$after $50 \mathrm{~min}$ and $\mathrm{his}^{+}$after $48 \mathrm{~min}$, and the R4 derivative transferred $\mathrm{rtl}^{+}$after $62 \mathrm{~min}$ and $\mathrm{his}^{+}$after $64 \mathrm{~min}$, consistent with chromosomal locations for $\mathrm{rl}^{+}$and $\mathrm{his}^{+}$ near $46 \mathrm{~min}$ and $44 \mathrm{~min}$, respectively. Of $2000 \mathrm{rtl}^{+}$transconjugants tested, all were resistant to kanamycin and none utilized galactitol.

It seemed that $\mathrm{rll}^{+}$genes and a kanamycin resistance determinant were located in the $\mathrm{Hfr}$ chromosome at about $46 \mathrm{~min}$. However, $\mathrm{rtl}^{+} \mathrm{Kan}^{\mathrm{R}}$ need not have been in that position in the original hybrids, but might have been part of a plasmid derived from $\mathrm{pE} 10$ and capable of integration into the chromosome. If $\mathrm{rl}^{+}$was plasmid-borne in the four hybrids, then it should be transducible into recA bacteria. Alaeddinoglu (1976) showed pE10 to be transducible by P1kc into recA recipients, whilst chromosomal markers were not. Phage grown on hybrids MW5651 and MW5652 were used to transduce KL144 ( $\operatorname{rroC}$ rec $A$ ) and AB1621 ( $x y l$ rec $\left.A^{+}\right)$, selection being made for $\mathrm{Rtl}^{+}, \mathrm{Aro}^{+}$and kanamycin resistance when $\mathrm{KL} 144$ was recipient, and for $\mathrm{Rtl}^{+}$ and $\mathrm{Xyl}^{+}$when $\mathrm{AB} 1621$ was recipient (Table 6). AB1621 served as a positive control to show that $\mathrm{rtl}^{+}$was transducible. Neither $\mathrm{aroC}^{+}$nor $\mathrm{rtl}^{+}$transductants of KL144 were obtained, whereas kanamycin resistant colonies occurred at low frequencies (one per $2 \times 10^{7}$ phage). Kanamycin resistant transductants did not utilize ribitol, but were resistant to chloramphenicol, neomycin, 
tetracycline and ampicillin. Both $\mathrm{rtl}^{+}$and $\mathrm{xyl}^{+}$transductants of $\mathrm{AB} 1621$ were obtained with satisfactory frequencies. When tested, $\mathrm{rll}^{+}$transductants were resistant to kanamycin but not to the other antibiotics and did not utilize galactitol. Judging from the evidence, the original hybrids contained two kanamycin resistance determinants, one linked to $\mathrm{rt}^{+}$at about $46 \mathrm{~min}$ of the linkage map, and a second carried by pE10 or a derivative.

\section{DISCUSSION}

Crossing over in homologous regions flanking the $r t$ atl and gat regions would explain the mutually exclusive behaviour of the genes. Frequencies of transduction were comparable with frequencies for other genes, suggesting that the heterologous regions did not seriously interfere with crossing over and may be no more than a few genes long. Transductants were stable, giving no evidence of partial diploidy and pointing to considerable homology in the region.

Crossing over may have occurred in the heterologous region, but failed to be detected because of either the selections used or inviability of the recombinants. Incomplete exchange may give the observed results if smaller intrageneric regions conferred specificity on the enzymes or control systems.

An R plasmid proved useful for transferring $\mathrm{rl}^{+}$from RK65 $\left(\mathrm{rtl}^{+} \mathrm{Atl}^{-}\right)$to $\mathrm{K} 12 ; \mathrm{rl}^{+}$mapped near metG. The complication that $r \mathrm{rl}^{+}$was $100 \%$ cotransducible with a kanamycin resistance determinant derived from the plasmid does not alter the previous findings. The extent of the affinity between $\mathrm{rll}^{+}$and $\mathrm{kan}^{+}$is unclear. It may be that $\mathrm{kan}$ was a transposable element that became transposed during the mobilization of the $\mathrm{rl}^{+}$genes, or was necessary for mobilization. Phage P1 clr100KM carries a gene for kanamycin resistance, but there was no evidence that it became transposed during the transductions.

Differential segments of DNA may represent adaptation to different selective pressures (or, perhaps, different adaptations to the same selective pressure); such differences may prove useful in classifying strains as for Salmonella subtyping (e.g. Old, 1977). Similarities of gene order and function between $\mathrm{rll}^{+}, \mathrm{atl}^{+}$and $\mathrm{gat}^{+}$genes makes attractive the possibility of evolution from genes encoding less specific enzymes acting on polyols $(\mathrm{Wu}, 1976 a, b)$. The $50 \%$ of strains which display none of the characters may possess other genes, or latent sequences or evolutionary remnants. If the regions immediately flanking the $\mathrm{rtl}^{+} \mathrm{atl}^{+}$and $\mathrm{gat}^{+}$genes are largely homologous in most wild strains, then the genes may have evolved by divergence in their position (Rigby et al., 1974). If the genes are grouped with genes for other polymorphic characters, these groups would resemble the supergenes associated with polymorphism in higher organisms (Darlington \& Mather, 1949).

Woodward \& Charles (1982) introduced the concept of an ideal $E$. coli chromosome with characteristic positions for all genes, including luxury ones, most wild strains possessing only a proportion of luxury genes, or possessing only a proportion in an active form. They accepted that over larger chromosome distances, large blocks of genes were likely to be in different positions in different strains. The present experiments show that the concept must allow for different genes, or longer lengths of DNA, behaving as alternatives in the chromosome. Alaeddinoglu \& Charles (1979) have already reported that genes for sucrose and D-serine utilization also behave as alternatives, but there is evidence that those genes may coexist in the chromosome in some strains (Hill, 1980).

The authors acknowledge the grant of an SRC studentship to M. J. Woodward.

\section{REFERENCES}

Adelberg, E. A., Mandel, M. \& Chen, G. C. C. (1965). Optimal conditions for mutagenesis by $N$ methyl- $N^{\prime}$-nitro- $N$-nitrosoguanidine in Escherichia coli K12. Biochemical and Biophysical Research Communications 18, 788-795.

AlAEdDinoglu, N. G. (1976). Genetical analysis of variation in the ability to utilize sucrose in strains of
Escherichia coli. Ph.D. thesis, Reading University, U.K.

Alaeddinoglu, N. G. \& Charles, H. P. (1979). Transfer of a gene for sucrose utilization into Escherichia coli $\mathrm{K} 12$, and consequent failure of expression of genes for D-serine utilization. Journal of General Microbiology 110, 47-59. 
BACHMANN, B. J. \& Low, K. B. (1980). Linkage map of Escherichia coli K12, edition 6. Microbiological Reviews 44, 1-56.

Blumenthal, T. (1972). P1 transduction: formation of heterogenotes upon cotransduction of bacterial genes with a P2 prophage. Virology 47, 76-93.

Cannon, F. C., Dixon, R. A., Postgate, J. R. \& PRIMrose, S. B. (1974). Chromosomal integration of Klebsiella nitrogen fixation genes in Escherichia coli. Journal of General Microbiology 80, 227-239.

Charnetzky, W. T. \& Mortlock, R. P. (1974a). Ribitol catabolic pathway in Klebsiella aerogenes. Journal of Bacteriology 119, 162-169.

Charnetzky, W. T. \& MoRTLOCK, R. P. (1974b). Darabitol catabolic pathway in Klebsiella aerogenes. Journal of Bacteriology 119, 170-175.

CharnetzKy, W. T. \& Mortlock, R. P. (1974c). Close genetic linkage of the determinants of the ribitol and D-arabitol pathways in Klebsiella aerogenes. Journal of Bacteriology 119, 176-182.

Clark, A. J. \& MARguiles, A. D. (1965). Isolation and characterization of recombination deficient mutants of Escherichia coli K12. Proceedings of the National Academy of Sciences of the United States of America 53, 451-459.

Colson, C., Glover, S. W., Symonds, N. \& Stacey, N. A. (1965). The location of the genes for host controlled modification and restriction in Escherichia coli K12. Genetics 52, 1043-1050.

CoOper, P. H., Hirshifield, I. N. \& MaAs, W. K. (1969). Map location of arginyl tRNA synthetase mutations in Escherichia coli K12. Molecular and General Genetics 104, 383-390.

CowAN, S. T. \& STEel, K. J. (1974). Manual for the identification of medical bacteria, 2nd edn. Cambridge : Cambridge University Press.

Darlington, C. D. \& MATHER, K. (1949). The elements of genetics. London: Allen \& Unwin.

EDWARDS, P. R. \& EwING, W. H. (1972). Identification of Enterobacteriaceae, $3 \mathrm{rd}$ edn. Minneapolis : Burgess Publishing.

FERENCI, T. \& KORNBERG, H. L. (1973). The utilization of fructose by Escherichia coli. Properties of a mutant defective in fructose-1-phosphate kinase. Biochemical Journal 132, 341-347.

Goldberg, R. B., Bender, R. A. \& STreicher, S. L. (1974). Direct selection for Pl-sensitive mutants of enteric bacteria. Journal of Bacteriology 118, 810814.

HILL, S. H. A. (1980). Genetic analysis of variation in Escherichia coli. Ph.D. thesis, Reading University, U.K.

Hill, S. H. A. \& Charles, H. P. (1980). Genetical analysis of natural variation in sucrose utilization in Escherichia coli. Society for General Microbiology Quarterly 7, 82.

INDERLIED, C. B. \& MORTLOCK, R. P. (1977). Growth of Klebsiella aerogenes on xylitol; implications for bacterial enzyme evolution. Journal of Molecular Evolution 9, 181-190.

LENGELER, J. (1975a). Mutations affecting transport of hexitols D-mannitol, D-glucitol and galactitol. Journal of Bacteriology 124, 26-38.

LENGELER, J. $(1975 b)$. Nature and properties of hexitol transport systems in Escherichia coli. Journal of Bacteriology 124, 39-47.
LENGELER, J. (1977). Analysis of mutations affecting the dissimilation of galactitol in Escherichia coli K12. Molecular and General Genetics 152, 83-91.

LENGELER, J. \& SteInberger, H. (1978). Analysis of regulating mechanisms controlling the synthesis of the hexitol transport systems in Escherichia coli. Molecular and General Genetics 164, 163-169.

Low, B. (1973). Rapid mapping of conditional and auxotrophic mutations in Escherichia coli K12. Journal of Bacteriology 113, 798-812.

MCCONVILlE, M. L. (1977). A study of mutants of Escherichia coli defective in haem synthesis. Ph.D. thesis, Reading University, U.K.

McConville, M. L. \& Charles, H. P. (1979). Isolation of haemin-requiring mutants of Escherichia coli K12. Journal of General Microbiology 113, 155-164.

Mortlock, R. P., Fossitt, D. D. \& Wood, W. A. (1965). A basis for utilization of unnatural pentoses and pentitols by Aerobacter aerogenes. Proceedings of the National Academy of Sciences of the United States of America 57, 572-579.

OLD, D. C. (1977). The utilization of pentoses and pentitols by different biotypes of Salmonella typhimurium. Journal of General Microbiology 101, 337-339.

Pauli, G. \& OVerath, P. (1972). The ato operon: a highly inducible system for acetoacetate and butyrate degradation in Escherichia coli. European Journal of Biochemistry 29, 553-562.

Pittard, J., Loutit, J. S. \& Adelberg, E. A. (1963). Gene transfer by $F$ prime strains of Escherichia coli K12. I. Delay in initiation of chromosome transfer. Journal of Bacteriology 85, 1394-1401.

Regves, P. (1959). Studies in bacterial genetics. Ph.D. thesis, London University, U.K.

REINER, A. M. (1975). Genes for ribitol and D-arabitol catabolism in Escherichia coli: their loci in Escherichia coli $\mathrm{C}$ and absence in $\mathrm{K} 12$ and B strains. Journal of Bacteriology 123, 530-536.

Rigby, P. W. J., Burleigh, B. D. \& Hartley, B. S. (1974). Gene duplication in experimental enzyme evolution. Nature, London 251, 200-204.

Rigby, P. W. J., Gething, M. J. \& Hartley, B. S. (1976). Construction of intergeneric hybrids using bacteriophage P1CM: transfer of the Klebsiella aerogenes ribitol dehydrogenase gene to Escherichia coli. Journal of Bacteriology 125, 728-738.

Salisbury, V., Hedges, R. W. \& DatTa, N. (1972). Two modes of curing transmissible bacterial plasmids. Journal of General Microbiology 70, 443-452.

Scangos, G. A. \& ReIner, A. M. (1978). Ribitol and Darabitol catabolism in Escherichia coli. Journal of Bacteriology 134, 492-500.

TOMOEdA, M., INUZUKA, M., KUBO, N. \& NAKAMURA, S. (1968). Effective elimination of drug resistance and sex factors in Escherichia coli by sodium dodecyl sulphate. Journal of Bacteriology 95, 1078-1089.

WOODWARD, M. J. (1980). Genetic analysis of variation in Escherichia coli. Ph.D. thesis, Reading University, U.K.

Woodward, M. J. \& Charles, H. P. (1980). Introduction of genes for sorbose utilization into Escherichia coli K12. Society for General Microbiology Quarterly 7, 81.

Woodward, M. J. \& Charles, H. P. (1982). Genes for L-sorbose utilization in Escherichia coli. Journal of General Microbiology 128, 1969-1980. 
WU, T. T. (1976a). Growth of a mutant of Escherichia coli $\mathrm{K} 12$ on xylitol by recruiting enzymes for $\mathrm{D}$-xylose and L-1,2-propanediol metabolism. Biochimica et biophysica acta 428, 656-663.

WU, T. T. (1976b). Growth on D-arabitol of a mutant strain of Escherichia coli K12 using a novel dehydrogenase and enzymes related to L-1,2-propanediol and
D-xylose metabolism. Journal of General Microbiology 94, 246-256.

Wu, T. T., Lin, E. C. C. \& Tanaka, S. (1968). Mutants of Aerobacter aerogenes capable of utilizing xylitol as a novel source of carbon. Journal of Bacteriology 96, 447-456. 